\title{
Collaboration of homologous recombination and nonhomologous end-joining factors for the survival and integrity of mice and cells
}

\author{
Chrystelle Couëdel, ${ }^{1}$ Kevin D. Mills, ${ }^{4}$ Marco Barchi, ${ }^{1}$ Lingbo Shen, ${ }^{2}$ Adam Olshen, ${ }^{3}$ \\ Roger D. Johnson, ${ }^{1,5}$ André Nussenzweig, ${ }^{6}$ Jeroen Essers, ${ }^{7}$ Roland Kanaar, ${ }^{7}$ Gloria C. Li, ${ }^{2}$ \\ Frederick W. Alt, ${ }^{4,8}$ and Maria Jasin ${ }^{1,9}$ \\ ${ }^{1}$ Molecular Biology Program, ${ }^{2}$ Department of Medical Physics and Department of Radiation Oncology, and ${ }^{3}$ Department of \\ Epidemiology and Biostatistics, Memorial Sloan-Kettering Cancer Center, New York, New York 10021, USA; ${ }^{4}$ CBR Institute \\ for Biomedical Research, Boston, Massachusetts 02115, USA; ${ }^{5}$ Cancer Center and Department of Cell Biology, University of \\ Massachusetts Medical School, Worcester, Massachusetts 01605, USA; ${ }^{6}$ Experimental Immunology Branch, National Cancer \\ Institute, National Institutes of Health, Bethesda, Maryland 20892, USA; ${ }^{7}$ Department of Cell Biology and Genetics, and \\ Department of Radiation Oncology, Erasmus MC, 3000 DR Rotterdam, The Netherlands; ${ }^{8}$ Howard Hughes Medical \\ Institute, The Children's Hospital, Boston, Massachusetts 02115, USA
}

Homologous recombination (HR) and nonhomologous end-joining (NHEJ) are mechanistically distinct DNA repair pathways that contribute substantially to double-strand break (DSB) repair in mammalian cells. We have combined mutations in factors from both repair pathways, the HR protein Rad54 and the DNA-end-binding factor Ku80, which has a role in NHEJ. Rad54 $4^{-1-} \mathrm{Ku}^{-1 /-}$ mice were severely compromised in their survival, such that fewer double mutants were born than expected, and only a small proportion of those born reached adulthood. However, double-mutant mice died at lower frequency from tumors than Ku80 single mutant mice, likely as a result of rapid demise at a young age from other causes. When challenged with an exogenous DNA damaging agent, ionizing radiation, double-mutant mice were exquisitely sensitive to low doses. Tissues and cells from double-mutant mice also showed indications of spontaneous DNA damage.

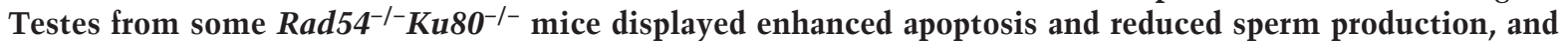
embryonic fibroblasts from $\mathrm{Rad} 54^{-/-} \mathrm{Ku}^{-1 /-}$ animals accumulated foci of $\gamma$-H2AX, a marker for DSBs. The substantially increased DNA damage response in the double mutants implies a cooperation of the two DSB repair pathways for survival and genomic integrity in the animal.

[Keywords: DNA double-strand break; homologous recombination; nonhomologous end-joining; Ku80, Rad54]

Supplemental material is available at http://www.genesdev.org.

Received April 5, 2004; revised version accepted April 23, 2004.

Cells have evolved numerous repair pathways to contend with various types of DNA damage. One type of lesion, a DNA double-strand break (DSB), poses a particular threat to genomic integrity, as misrepair of DSBs can lead to gross chromosomal rearrangements and other mutagenic events (van Gent et al. 2001; Mills et al. 2003). DSBs are initiators of genetically programmed processes, such as $V(D) J$ recombination and meiotic exchange, but they arise more generally in all cells from DNA replication, oxidative metabolism, and other endogenous processes. DSBs are also considered to be the

${ }^{9}$ Corresponding author.

E-MAIL m-jasin@ski.mskcc.org; FAX (212) 717-3317.

Article and publication are at http://www.genesdev.org/cgi/doi/10.1101/ gad.1209204. relevant lesion for cell lethality after treatment with ionizing radiation (IR). If left unrepaired or if misrepaired, DSBs can result in permanent cell cycle arrest, cell death, or tumorigenesis (Pierce et al. 2001b).

Homologous recombination (HR) has long been known to be the predominant pathway for the repair of DSBs in yeast and bacteria (Paques and Haber 1999; Cromie et al. 2001), and direct examination of DSB repair supports a major role for HR in mammalian cells as well (Rouet et al. 1994; Liang et al. 1998). HR uses an unbroken, homologous sequence to template repair of the DSB, in a process involving members of the conserved Rad52 epistasis group (Symington 2002; West 2003), as well as other less-conserved factors, such as the tumor suppressor BRCA2 (Jasin 2002). Loss of most HR factors leads to early or mid-embryonic lethality in mice (Pierce 
et al. 2001b; van Gent et al. 2001), suggesting an essential role for HR in development, presumably to repair spontaneously arising DNA damage. An exception is the Rad54 protein, for which the mouse disruption shows no overt phenotype (Essers et al. 1997, 2000), likely because DSB-promoted HR is only mildly compromised in Rad54 ${ }^{-/}$cells (Dronkert et al. 2000).

A second prominent pathway for DSB repair in mammalian cells is nonhomologous end-joining (NHEJ), in which broken ends are healed without the requirement for significant sequence homology (Pierce et al. 2001b; van Gent et al. 2001). NHEJ factors have been identified that play important roles in DSB repair after IR damage and during $V(D) J$ recombination, including the DNAend-binding $\mathrm{Ku} 70 / \mathrm{Ku} 80$ heterodimer, the protein kinase DNA-PKcs, and the XRCC4/DNA ligase IV complex (Mills et al. 2003). Loss of NHEJ factors results in late embryonic death for some factors (i.e., XRCC4 and DNA ligase IV), but not for others (i.e., $\mathrm{Ku} 80, \mathrm{Ku} 70$, and DNAPKcs; Pierce et al. 2001b; van Gent et al. 2001; Mills et al. 2003), although loss of Ku80 or Ku70 leads to a number of phenotypes, including small size and early death, as well as immunodeficiency (Nussenzweig et al. 1996; $\mathrm{Gu}$ et al. 1997; Li et al. 1998). Thus, either NHEJ does not play as important a role in development as HR, or other NHEJ factors with key roles in development remain to be identified.

DSBs that serve as initiators of genetically programmed processes are directed into either NHEJ or HR; for example, DSBs introduced by the RAG proteins during $V(D) J$ recombination are repaired by the NHEJ pathway (Mills et al. 2003), whereas those introduced by the Spoll protein during meiosis are repaired by the HR pathway (Keeney 2001). Less is known about the relative contribution of NHEJ and HR to the repair of DNA damage that is not genetically programmed, although one factor that influences repair pathway choice is cell cycle phase. NHEJ is preferred during G1/early $S$ phase, whereas HR is prominent in late S/G2 phase (Takata et al. 1998; Rothkamm et al. 2003). However, these preferences do not appear to be absolute (Rothkamm et al. 2003), and there is evidence that both pathways have access to the same DSB. For example, HR and NHEJ can be coupled for the repair of a single DSB (Richardson and Jasin 2000). In addition, in NHEJ mutants, HR repair of a DSB is increased compared with wild-type cells, suggesting that HR can compensate when NHEJ is impaired (Pierce et al. 2001a; Allen et al. 2002; Delacote et al. 2002). This increase is particularly striking in Ku mutant cells compared with other NHEJ mutants (Pierce et al. 2001a).

To begin to understand the cooperation between HR and NHEJ in the mouse, we combined a mild HR mutation, that is, loss of Rad54, with a moderate NHEJ mutation, that is, loss of Ku80. We find that the survival of Rad54 ${ }^{-1-} \mathrm{Ku} 80^{-/-}$mice is severely compromised, even when compared with $\mathrm{Ku} 8 \mathrm{O}^{-/-}$mice, revealing a vital role for Rad54 in the support of $\mathrm{Ku} 80^{-/-}$mouse viability. Although Rad54 ${ }^{-1}$ mice are not sensitive to IR (Essers et

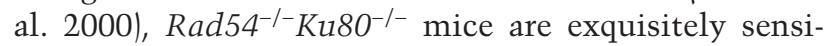

tive, much more so than $\mathrm{Ku} 80^{-/-}$mice. Consistent with a collaborative role for $\mathrm{Rad} 54$ and $\mathrm{Ku}$ in the repair of spontaneously arising DNA damage, embryonic fibroblasts from double-mutant animals accumulate large numbers of $\gamma$-H2AX foci, a marker for DSBs (Rogakou et al. 1998, 1999), as compared with single mutants. Apoptosis is also elevated in testes, compromising sperm production. These results imply that NHEJ and HR factors cooperate to repair DNA damage in mammalian cells. Moreover, these findings uncover a key role for Rad54 in the animal, suggesting that even a mild repair deficiency can have profound effects in the context of other mutations.

\section{Results}

Rad54 mutation impairs the embryonic viability of $\mathrm{Ku} 80^{-1-}$ mice

To investigate the effect of combined Rad54 and Ku80 mutation in mice, we set up crosses to generate

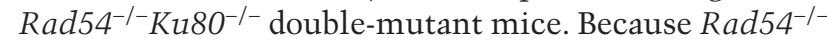
mice are fully fertile and viable (Essers et al. 1997), we

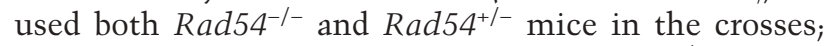
however, due to the small litter size of $\mathrm{Ku}^{-\mathrm{O}^{-/}}$mutant mice (Nussenzweig et al. 1996), we crossed only $\mathrm{Ku} 80^{+/-}$ mice. From our initial crosses, we did not obtain any Rad54 ${ }^{-1-} \mathrm{Ku} 80^{-1-}$ mice from litters genotyped at weaning. Therefore, we monitored animals starting at birth to determine whether double mutants would be represented among newborn animals. Rad54 ${ }^{-1-} \mathrm{Ku} 80^{-/-}$animals were recovered among the newborns, although at a significantly lower frequency than expected from the Mendelian ratios (Table 1A). (Data from different crosses are available in Supplementary Table 1.) Some of the newborns were dead at birth or died soon thereafter, but the majority was recovered alive (see below). The recovery of $\mathrm{Rad} 54^{+/-} \mathrm{Ku} 80^{-/-}$newborns was also lower than expected from the Mendelian ratios, although to a lesser extent than $\mathrm{Rad}_{54^{-1-}} \mathrm{Ku}^{-1} 0^{-/}$newborns $181.7 \%$ and $60.6 \%$, respectively), suggesting that heterozygosity at the Rad54 locus may have a small effect on the survival of $\mathrm{Ku}_{80} \mathrm{O}^{-/-}$mice to term. Ku80 ${ }^{-/-}$newborns were obtained at a somewhat lower frequency than expected $(86.2 \%)$, although this decrease was not significant. Importantly, the recovery of $\mathrm{Rad} 54^{-/-} \mathrm{Ku} 80^{-/-}$newborns, in addition to being lower than expected among all progeny, was also significantly lower than either the $\mathrm{Ku}^{8 \mathrm{O}^{-/}}$ or Rad54 ${ }^{+/} \mathrm{Ku} 80^{-/-}$newborns $(p<0.01$ for each; Table 1A). These results imply that combined mutation of the Ku80 and Rad54 DSB repair genes compromises the recovery of mice at birth, although only partially.

Mice with NHEJ deficiency have increased cell death in the developing nervous system, and a correlation has been made between the extent of neuronal cell death and embryonic survival ( $\mathrm{Gu}$ et al. 2000). To investigate the lethality observed for Rad54 ${ }^{-/} \mathrm{Ku} 80^{-/-}$mutants, brains, and spinal cords from embryonic day 13.5 (E13.5) and E18.5 embryos were analyzed for cell death using a DNA fragmentation assay, and results compared with litter- 


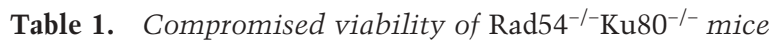

\begin{tabular}{|c|c|c|c|c|}
\hline \multirow[b]{2}{*}{ Genotype } & \multirow[b]{2}{*}{ Expected } & \multirow[b]{2}{*}{ Observed } & \multicolumn{2}{|c|}{ Recovery } \\
\hline & & & \multicolumn{2}{|c|}{ ( $p$-value vs $\mathrm{Rad} 54^{-/-} \mathrm{Ku} 80^{-/-}$) } \\
\hline \multicolumn{5}{|l|}{ A) Birth $(n=2054)$} \\
\hline $\mathrm{Ku} 80^{-1-}$ & 87 & 75 & $86.2 \%$ & $\begin{aligned} p & =0.20 \\
(p & =0.008)\end{aligned}$ \\
\hline Rad $54^{+/-} \mathrm{Ku} 80^{-/-}$ & 257 & 210 & $81.7 \%$ & $\begin{aligned} p & =0.001 \\
(p & =0.003)\end{aligned}$ \\
\hline $\mathrm{Rad}_{54^{-1-}} \mathrm{Ku} 80^{-/-}$ & 170 & 103 & $60.6 \%$ & $p<0.001$ \\
\hline \multicolumn{5}{|c|}{ B) Maternal Nursing $(n=854)$} \\
\hline $\mathrm{Ku} 80^{-/-}$ & 22 & 6 & $27.3 \%$ & $\begin{array}{c}p<0.001 \\
(p<0.001)\end{array}$ \\
\hline Rad54 $4^{+-} \mathrm{Ku} 80^{-/-}$ & 68 & 18 & $26.5 \%$ & $\begin{array}{c}p<0.001 \\
(p<0.001)\end{array}$ \\
\hline 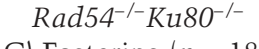 & 123 & 9 & $7.3 \%$ & $p<0.001$ \\
\hline \multicolumn{5}{|c|}{ C) Fostering $(n=1813)$} \\
\hline $\mathrm{Ku} 80^{-/-}$ & 77 & 33 & $42.9 \%$ & $\begin{array}{c}p<0.001 \\
(p<0.001)\end{array}$ \\
\hline Rad54 ${ }^{+/-} \mathrm{Ku}_{80} 0^{-/-}$ & 227 & 90 & $39.6 \%$ & $\begin{array}{c}p<0.001 \\
(p<0.001)\end{array}$ \\
\hline 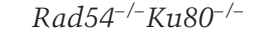 & 150 & 22 & $14.7 \%$ & $p<0.001$ \\
\hline
\end{tabular}

Mouse genotypes obtained from three types of crosses are summarized. (See Supplementary Table 1 for detailed counts from each type of cross.) Recovery is the observed number of mice at birth (A) or $21 \mathrm{~d}$ of age at weaning from the birth (B) or foster mother (C), relative to the number of mice expected from the Mendelian ratios. The p-value is indicated. The recovery of $\mathrm{Ku}^{80^{-/-}}$or $\mathrm{Rad} 54^{+/-} \mathrm{Ku} 80^{-/-}$mice

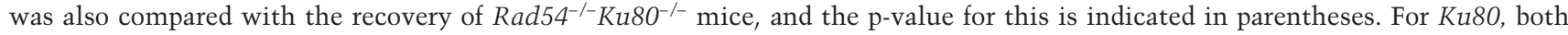
parents were heterozygous for the mutation, whereas for Rad54, parents were heterozygous, homozygous, or heterozygous and homozygous. Because the Rad54 mutant allele was overrepresented in the parents relative to the wild-type allele, the expected number of $\mathrm{Rad} 54^{+/+}$animals is low compared with the other genotypes.

(A) Total animals recovered at birth, whether they were alive or stillborn.

(B) Total animals alive at weaning, when nursed by their birth mother.

(C) Total animals alive at weaning, when nursed by foster mothers.

mate controls. TUNEL-positive nuclei were occasionally detected in Rad54 ${ }^{-/-}$embryos (Supplementary Fig. 1A,E; data not shown), although the number was only marginally increased - that is, approximately twofold for E13.5 embryos-compared with wild-type embryos (data not shown). In contrast, in $\mathrm{Ku} 80^{-/-}$E13.5 embryos, apoptotic cells were increased two orders of magnitude or more (Supplementary Fig. 1B,F; see also Gu et al. 2000). We also observed increased apoptosis in the brain of $\mathrm{Ku}_{80} \mathrm{O}^{-/-}$ E18.5 embryos, although the level of apoptosis was not as dramatically increased as in E13.5 embryos (Supple-

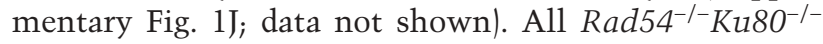
embryos at both E13.5 and E18.5 also had a large number of TUNEL-positive nuclei in the developing brain and spinal cord (Supplementary Fig. 1D,H,L), similar to the $\mathrm{Ku} 8 \mathrm{O}^{-/-}$embryos. However, variability between embryos precluded us from determining whether the level of apoptosis in the double mutant was significantly increased compared with the single mutant. Nevertheless, the lack of a substantially increased level of apoptosis in the Rad54 $4^{-I-} \mathrm{Ku} 80^{-/-}$embryos is consistent with the completion of embryogenesis for the majority of embryos.

\section{Rad54 mutation reduces the postnatal viability} of $\mathrm{Ku} 80^{-/-}$mice

Although combined mutation of the Ku80 and Rad54 DSB repair genes compromised the recovery of mice at birth, a substantial portion of double-mutant mice was recovered. To determine whether we could obtain adult animals, we therefore expanded the number of crosses and allowed the dams to nurse their progeny until weaning at 3 wk of age, at which point the animals were genotyped (Table 1B). Ku 80 mutation alone led to a significant impairment in the survival of mice, as has been described previously (Nussenzweig et al. 1996), such that only $27.3 \%$ of $\mathrm{Ku}_{80} \mathrm{O}^{-/-}$mice expected from the Mendelian ratios were alive at weaning. Similar results were obtained with the $\mathrm{Rad} 54^{+/-} \mathrm{Ku} 80^{-/-}$mice, with only $26.5 \%$ of the expected number of mice recovered. How-

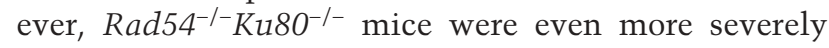
compromised in their survival, with only $7.3 \%$ of the expected number of mice alive at weaning. The difference in recovery of viable double-mutant mice was highly significant compared with either $\mathrm{Ku}^{-1-}$ or Rad54 ${ }^{+/-} \mathrm{Ku} 80^{-/-}$mice $(p<0.001$ for each; Table 1B), indicating that Rad54 mutation compromises the postnatal viability of $\mathrm{Ku}_{80} \mathrm{O}^{-/-}$mice.

$\mathrm{Ku} 8 \mathrm{O}^{-/-}$newborns are significantly smaller than wildtype and heterozygote littermates (Nussenzweig et al. 1996). Similarly, we found that $\mathrm{Rad} 54^{+/-} \mathrm{Ku} 80^{-/-}$and Rad54 $4^{-/-} \mathrm{Ku} 80^{-/-}$newborns are also dwarfs, not noticeably different in size from their $\mathrm{Ku} 80^{-/-}$littermates (see below). As a consequence, $\mathrm{Ku} 80^{-/-}$mutants of any Rad54 genotype could be easily identified among the newborns and placed with foster mothers to prevent pos- 
sible death due to competition for resources with their larger littermates. For each mutant, we found that fostering improved survival to weaning approximately twofold, although the expected number of mice was still not obtained (Table 1C). Again, the survival of Rad54 ${ }^{-/} \mathrm{Ku} 80^{-/-}$mice was still significantly compromised relative to either $\mathrm{Rad} 54^{+/-} \mathrm{Ku} 80^{-/-}$or $\mathrm{Ku} 80^{-/-}$ mice, such that only about one-third as many double mutants were obtained at weaning $(14.7 \%$ relative to $39.6 \%$ or $42.9 \%$, respectively; $p<0.001$ for each). These results indicate the reduced fitness of the Rad54 $4^{-I-} \mathrm{Ku} 80^{-/-}$mice, and thus a contribution of both DSB repair genes to survival of the animal.

\section{Rad54 mutation shortens the lifespan of $\mathrm{Ku} 80^{-/-}$mice}

The difference in survival of $\mathrm{Rad} 54^{-/-} \mathrm{Ku} 80^{-/-}$mice by the time of weaning relative to $\mathrm{Ku}^{-1 /-}$ mice led us to examine their postnatal survival in more detail. Fostered animals were monitored daily so that dead animals could be genotyped, including dead newborns (Fig. 1). Perinatal mortality was observed for all three $\mathrm{Ku} 8 \mathrm{O}^{-/-}$genotypes (Fig. 1A). Approximately $10 \%$ of the $\mathrm{Ku}^{-\mathrm{O}^{-/-}}$animals and $20 \%$ of both the $\mathrm{Rad} 54^{+/-} \mathrm{Ku} 80^{-/-}$and $\mathrm{Rad} 54^{-/-} \mathrm{Ku} 80^{-/-}$ animals that were born were either stillborn or died during the first day after birth (day 0). Despite fostering, $50 \%$ of the $\mathrm{Ku} 80^{-/-}$and $\mathrm{Rad} 54^{+/-} \mathrm{Ku} 80^{-/-}$mutants that were born were dead within $3 \mathrm{~d}$ after birth, at which point the animals' viability stabilized until weaning at 3 wk of age, such that at weaning, $44 \%$ and $43 \%$, respectively, of animals that were obtained at birth were still alive. However, $\mathrm{Rad} 54^{-/-} \mathrm{Ku} 80^{-/-}$mice died more precipitously in the first week or so after birth. The cause of death is unknown, but it was observed that some Rad54 ${ }^{-/-} \mathrm{Ku} 80^{-/-}$mice that died perinatally had difficulty breathing and had not fully inflated their lungs (data not shown). Double-mutant mice continued to die until weaning, although at a slower rate than in the days immediately after birth. As a result, only $21 \%$ of the double-mutant mice were still alive at weaning.

After weaning, we continued to observe the fostered mice for survival (Fig. 1B). In contrast to Rad54 ${ }^{-/-}$mice, all three $\mathrm{Ku} 80^{-/-}$genotypes experienced a decline in the number of surviving animals in the first few weeks after weaning, implying that separation from the foster mother impaired survival. The decline in the number of surviving animals was again more precipitous for the double-

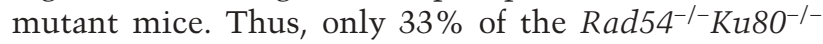
mice that were alive at weaning were still alive at $8 \mathrm{wk}$ of age, whereas for either the $\mathrm{Ku} 80^{-/-}$or $\mathrm{Rad} 54^{+/-} \mathrm{Ku} 80^{-/-}$ mice $>75 \%$ of the mice were still alive at this age. After this point, the death rate decreased, such that by 7 mo of age, only a fraction of the mice that were weaned were still alive $\left(\sim 30 \%\right.$ for $\mathrm{Ku} 80^{-/-}$and $\mathrm{Rad} 54^{+/-} \mathrm{Ku} 80^{-/-} ; 7 \%$

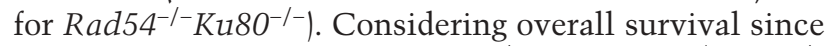
birth, $14 \%$ and $12 \%$ of the $\mathrm{Ku} 80^{-/-}$and $\mathrm{Rad} 54^{+/-} \mathrm{Ku} 80^{-/-}$ mice, respectively, were still alive at $7 \mathrm{mo}$ of age, in contrast to $1.5 \%$ of the $\mathrm{Rad}_{54^{-/-}} \mathrm{Ku} 80^{-/-}$mice.

As $\mathrm{Ku} 80^{-/-}$mice are smaller than their wild-type counterparts, the increased mortality of $\mathrm{Rad}_{54^{-I-}} \mathrm{Ku} 80^{-/-}$ mice could be related to increased frailness due to poor
A Survival of mice during fostering

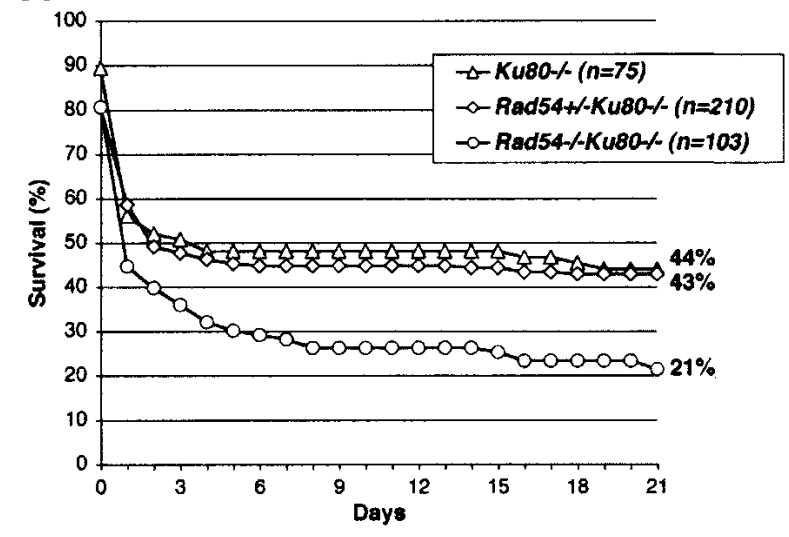

B Survival of mice after weaning from foster mothers

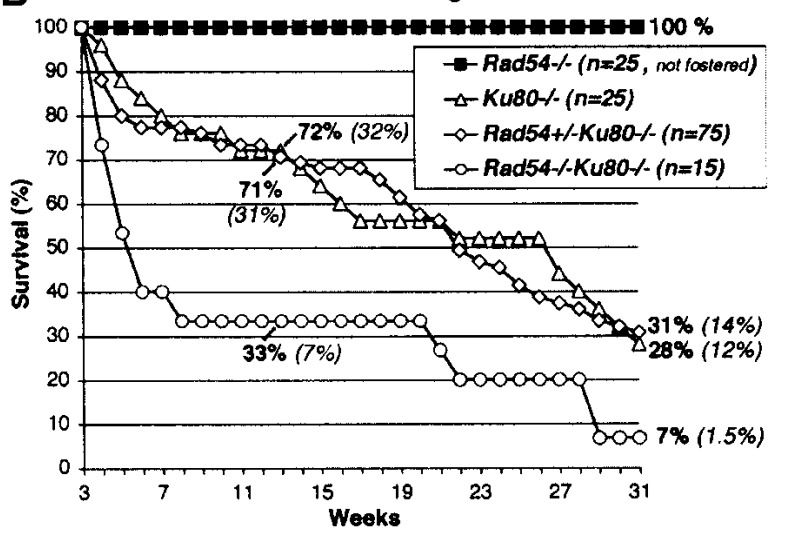

Figure 1. Impaired postnatal survival of $\mathrm{Rad}_{54} 4^{-1-} \mathrm{Ku} 80^{-1-}$ mice. The total number of mice for each genotype $(\mathrm{n})$ is indicated. (A) Survival of mice during fostering. Curves begin at birth. Total numbers at birth include animals that were stillborn. Percentage of mice still alive at weaning (i.e., $21 \mathrm{~d}$ of age) is indicated at right. (B) Survival of mice after weaning from foster mothers. Curves begin with mice that were alive at weaning (i.e., $21 \mathrm{~d}$ of age). As a reference, a survival curve of Rad54-/mice that were nursed by their birth mother is depicted. Percentage of weaned mice still alive at 3 or 7 mo of age is indicated; in parentheses, the percentage of mice still alive at 3 or 7 mo relative to the total number of mice recovered at birth is also indicated.

weight gain. To examine this, male and female mice were weighed once a week over a 6-mo period, starting at $10 \mathrm{~d}$ of age (Fig. 2A,B). Like Ku80 ${ }^{-/-}$

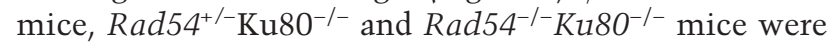
significantly smaller than control mice. Rad54 mutation, however, had little effect on the size of $\mathrm{Ku} 80^{-/-}$ mice, as the double mutants weighed, on average, only $10 \%$ less than the single mutants. After an initial growth spurt during the first $45 \mathrm{~d}$ or so of life, the weight gain of all three Ku80 genotypes became shallower and then leveled off at $\sim 15 \mathrm{~g}$. This contrasts with $\mathrm{Rad} 54^{-/-}$and control mice, which had a steeper initial growth spurt and then continued to gain weight over the course of the experiment.

To gain further insight into the underlying pathology leading to the death of the mutant animals, several mice 


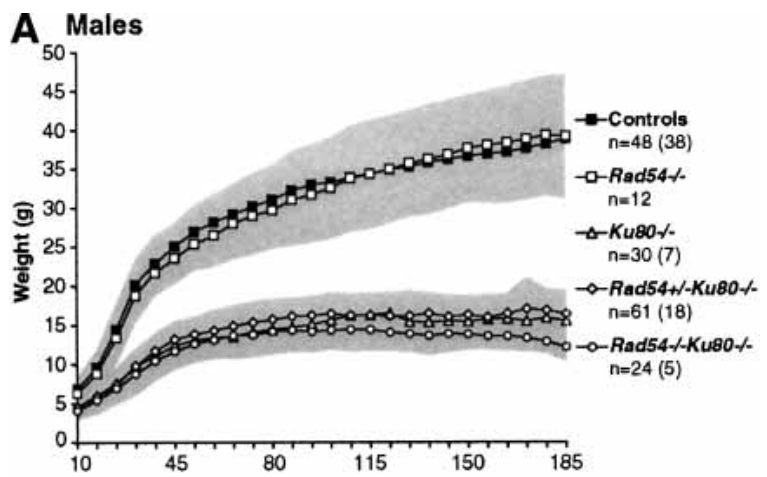

B Females

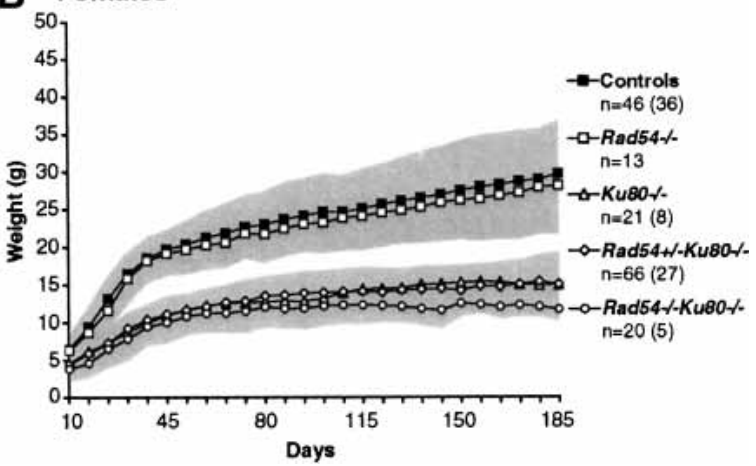

Figure 2. Growth retardation of $\mathrm{Ku} 80^{-/-}$mice, regardless of Rad54 genotype. Males $(A)$ and females $(B)$ were weighed once a week starting $10 \mathrm{~d}$ after birth. Average weights of control mice (i.e., wild-type mice or mice heterozygote for either Rad54 or Ku80 mutation, or both) and $\mathrm{Rad}_{54^{-1-}}$, $\mathrm{Ku} 80^{-/-}$,

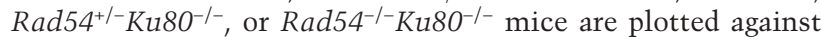
days after birth. The total number of mice for each genotype (n) is indicated. Because some mice died or were sacrificed during the observation period for other analyses, the number of mice remaining at the end of the study is reduced and is indicated in parentheses. Gray areas indicate weight variations based on standard deviations.

from each genotype were necropsied. Gross observation indicated lymphoid deficiency in $\mathrm{Ku}^{-1-}$ mice of each Rad54 genotype (data not shown), as would be expected by Ku deficiency. Mice that died from $\sim 10 \mathrm{~d}$ to 3 mo of age generally showed no other significant lesion (Table 2). Mice older than $3 \mathrm{mo}$, however, were often found to have infections, presumably as a result of impaired immune system function, and in addition, lymphomas, although not other tumors. Neoplastic lymphocytes were found in the thymus, with extension to pulmonary interstitium, epicardium of the heart, and other tissues in a number of mice. A somewhat lower percentage of lymphomas in mice older than 3 mo of age was found in $\mathrm{Rad} 54^{-/-} \mathrm{Ku} 80^{-/-}$mice compared with $\mathrm{Ku}^{-10^{-/-}}$or Rad $54^{+/-} \mathrm{Ku}_{80^{-/-}}$mice (Table 2), although the difference was not significant ( $p=0.6$ for each). However, considering the lymphoma frequency in the entire cohort of

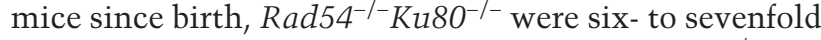
less likely to die from lymphoma than were $\mathrm{Ku} 8 \mathrm{O}^{-/-}$and Rad54 ${ }^{+/-} \mathrm{Ku}_{80^{-/-}}$mice (Table 2; $\mathrm{p}<0.01$, see Supplementary Table 2). This presumably highlights the reduced fitness of the $\mathrm{Rad} 54^{-/-} \mathrm{Ku} 80^{-/-}$mice, which leads to premature death from other causes, rather than an inability to undergo neoplastic transformation. Consistent with this, the mean age of death from lymphoma for all three Ku80 genotypes was similar, about 5 mo of age (Table 2).

Extreme radiation sensitivity of $\operatorname{Rad} 54^{-/-} \mathrm{Ku} 80^{-/-}$mice

Because both Rad54 and Ku80 have roles in DSB repair, the compromised survival of $\mathrm{Rad} 54^{-/-} \mathrm{Ku} 80^{-/-}$mice may be related to or the result of impaired DNA repair. To determine whether disruption of both genes affects the sensitivity of mice exposed to exogenous DNA damaging agents, we tested whether Rad54 mutation heightens the previously described radiation sensitivity of $\mathrm{Ku} 80^{-/-}$ mice (Nussenzweig et al. 1997). Rad54 ${ }^{-/-} \mathrm{Ku} 80^{-/-}$mice were exposed to ionizing radiation (IR) and compared for their survival to single mutant and control mice. Two- to four-month-old animals were used in this analysis, as there is little mortality during this time for any of the genotypes (Fig. 1B). Consistent with previous observations, all Rad54 $4^{-1-}$ mice survived 100 or 200 cGy of radiation

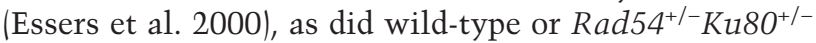
mice (Fig. 3). All $\mathrm{Ku} 80^{-/-}$and $\mathrm{Rad} 54^{+/-} \mathrm{Ku} 80^{-/-}$mice also

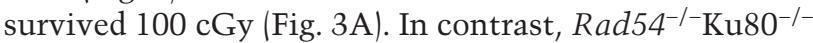
mice started to die $10 \mathrm{~d}$ after exposure to this dose and all were dead within $17 \mathrm{~d}$ of irradiation (Fig. 3A). At the

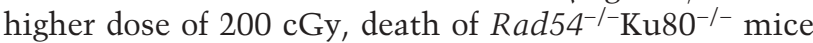
occurred earlier, starting $2 \mathrm{~d}$ after irradiation, and all were dead within $8 \mathrm{~d}$ (Fig. 3B). At this dose, $\mathrm{Ku} 8 \mathrm{O}^{-/-}$and Rad54 $4^{+/-} \mathrm{Ku} 80^{-/-}$mice presented an intermediate sensitivity, compared with the severely affected double mutants and the unaffected Rad54 $4^{-/-}$and control mice

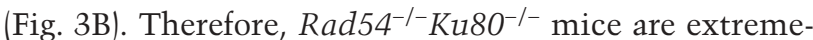
ly radiosensitive, more so than $\mathrm{Ku}^{-1} \mathrm{O}^{-/-}$mice, implying that both genes contribute to DNA repair in the adult animal.

\section{Accumulation of $\gamma$-H2AX foci in $\operatorname{Rad} 54^{-/-} \mathrm{Ku} 80^{-/-}$ embryonic fibroblasts}

Given the hypersensitivity of $\mathrm{Rad} 54^{-/-} \mathrm{Ku} 80^{-/-}$mice to IR, we surmised that the cells of the double-mutant animals could be compromised in their inability to repair spontaneously arising DNA damage. We determined whether spontaneous damage could be detected in Rad54 $4^{-/-} \mathrm{Ku} 80^{-/-}$cells in culture, using mouse embryonic fibroblasts (MEFs) obtained from E13.5 embryos. Consistent with previous results (Nussenzweig et al. 1996), proliferation of $\mathrm{Ku}_{80^{-/-}}$cells was severely impaired, as was BrdU incorporation (Supplementary Fig. 2). $\mathrm{Rad} 54^{+/-} \mathrm{Ku} 80^{-/-}$and $\mathrm{Rad} 54^{-/-} \mathrm{Ku} 80^{-/-}$cells exhibited a similar growth defect with minimal expansion over the 10-d culture period. These cells showed no sign of elevated apoptosis, however, as there was no increase in TUNEL-positive nuclei for $\mathrm{Ku} 80^{-/-}$or $\mathrm{Rad} 54^{-/-} \mathrm{Ku} 80^{-/-}$ cells compared with control cells (data not shown; also, see below), suggesting that the proliferation defect was 
Couëdel et al.

Table 2. Pathological assessment of mutant mice

\begin{tabular}{|c|c|c|c|c|c|c|c|c|}
\hline \multirow[b]{2}{*}{ Genotype } & \multirow[b]{2}{*}{ Age (months) } & \multirow[b]{2}{*}{ Viability $^{\mathrm{a}}$} & \multicolumn{4}{|c|}{ Pathology (number of mice) } & \multicolumn{2}{|c|}{ Lymphoma } \\
\hline & & & $\begin{array}{l}\text { Complete necropsy } \\
\text { total }\end{array}$ & $\begin{array}{l}\text { No significant } \\
\text { lesion }^{\mathrm{b}}\end{array}$ & Infection & 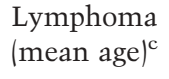 & $>3 \mathrm{mo}^{\mathrm{d}}$ & Overall $^{\mathrm{e}}$ \\
\hline \multirow[t]{2}{*}{$\mathrm{Ku} 80^{-/-}$} & $\leq 3$ & $68 \%$ & 9 & 8 & 1 & 0 & $81 \%$ & $20 \%$ \\
\hline & $>3$ & $32 \%$ & 13 & 1 & 5 & $8(24)$ & & \\
\hline \multirow[t]{2}{*}{ Rad54+/- $\mathrm{Ku} 80^{-/-}$} & $\leq 3$ & $69 \%$ & 4 & 4 & 0 & 0 & $62 \%$ & $19 \%$ \\
\hline & $>3$ & $31 \%$ & 8 & 0 & 3 & $5(22)$ & & \\
\hline \multirow[t]{2}{*}{ Rad54 ${ }^{-1-} \mathrm{Ku}_{80^{-1-}}$} & $\leq 3$ & $93 \%$ & 10 & 9 & 1 & 0 & $44 \%$ & $3 \%$ \\
\hline & $>3$ & $7 \%$ & 9 & 1 & 7 & $4(23.5)$ & & \\
\hline
\end{tabular}

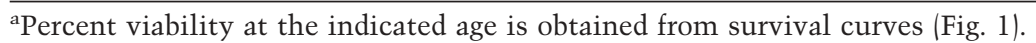

${ }^{b}$ Lymphoid deficiency is not included in this tabulation. Excluding one mouse, lymphoid deficiency was observed in all animals in which it could be evaluated. In some cases, autolysis precluded definitive evaluation of lymphoid deficiency, as did lymphoma, because infiltration by neoplastic lymphocytes may have obliterated the normal architecture of the organs.

${ }^{\mathrm{c}}$ Mean age of death from lymphoma is indicated in weeks in parentheses.

${ }^{\mathrm{d}}$ From necropsied mice older than 3 mo.

${ }^{\text {e}}$ From necropsied mice relative to the entire cohort since birth. See Supplementary Table 2 for calculation.

due to cell cycle arrest and/or senescence rather than cell death.

One of the first cellular responses to DSBs is phosphorylation of histone H2AX at sites of damage, which is visible as foci of $\gamma$-H2AX (i.e., phosphorylated $\mathrm{H} 2 \mathrm{AX}$; Rogakou et al. 1998, 1999). MEFs were subjected to indirect immunofluorescence to detect $\gamma$-H2AX foci and subsequently counterstained with DAPI to visualize nuclei. The majority of wild-type cells had no detectable

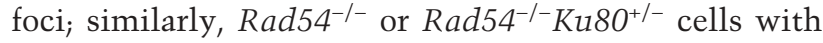
spontaneous foci were also infrequent (Fig. 4A; data not shown). In contrast, many $\mathrm{Ku} 80^{-/-}$cells and nearly all Rad54 ${ }^{-/} \mathrm{Ku} 80^{-/-}$cells were positive for $\gamma$-H2AX foci (Fig. 4A).

These results were quantified by counting the number of cells with $\gamma$-H2AX foci, and, in those cells, the number of foci. Spontaneously arising foci were detectable in $30 \%$ of Rad54 $4^{-/}$cells (Fig. 4B), and most of these positive cells had only a small number of foci (i.e., 1-5 foci; Fig. 4C). Wild-type cells showed a very similar number of cells with foci $(27 \%)$ and a similar distribution, with positive cells exhibiting only a few foci (Mills et al. 2004). More than twice as many $\mathrm{Ku}^{-0^{-/-}}$cells were found to have foci (i.e., 69\%; Fig. 4B). Most of the $\mathrm{Ku} 80^{-/-}$cells with foci had a small number of foci, although some cells had a moderate number (i.e., $6-10$ foci) or even a large number of foci ( $>10$ foci; Fig. $4 \mathrm{C})$. Strikingly, however, $>90 \%$ of the $\mathrm{Rad}_{54^{-/-}} \mathrm{Ku} 8 \mathrm{O}^{-/-}$cells had foci (Fig. 4B), and of these, the majority had a large number of foci (Fig. 4C). The increased number of cells with $\gamma$-H2AX foci was not the result of apoptosis, because TUNEL-positive cells were rare for all genotypes (data not shown), as were cleaved caspase-3-positive cells (Fig. 4D). These results imply an elevated level of DNA damage when $\mathrm{Ku} 80$ is disrupted, but a dramatically elevated level of DNA damage when both Ku80 and Rad54 are disrupted.

\section{Apoptosis in the testis of $\mathrm{Rad} 54^{-/-} \mathrm{Ku} 80^{-/-}$mice}

The high level of spontaneous $\gamma-\mathrm{H} 2 \mathrm{AX}$ foci in Rad54 $4^{--} \mathrm{Ku} 80^{-/-}$MEFs suggested that tissues composed of highly proliferative cells in adult animals would have cellular defects due to the accumulation of unrepaired DNA damage. Testis represents a tissue with a high proliferative capacity, in particular, the spermatogonia, the
Figure 3. Ionizing radiation sensitivity of

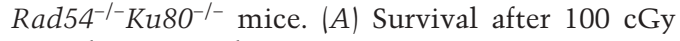
$\gamma$-irradiation. Each curve represents six mice. Controls are two mice each Rad54 ${ }^{-/-}, \mathrm{Rad}_{54^{+/-}} \mathrm{Ku} 8 \mathrm{O}^{+/-}$, and wild-type. (B) Survival after $200 \mathrm{cGy} \gamma$-irradiation. Each curve represents eight mice, except the controls, which are the same as in $A$.
A

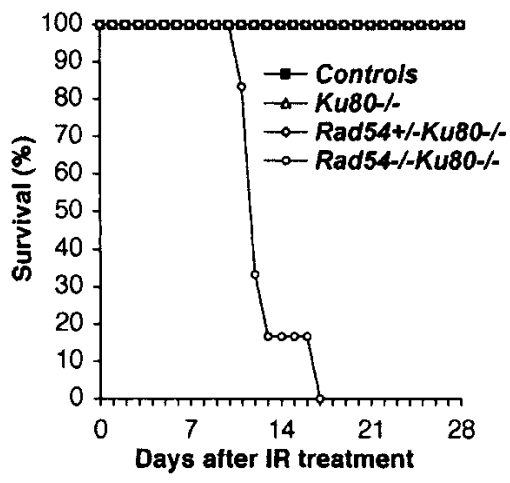

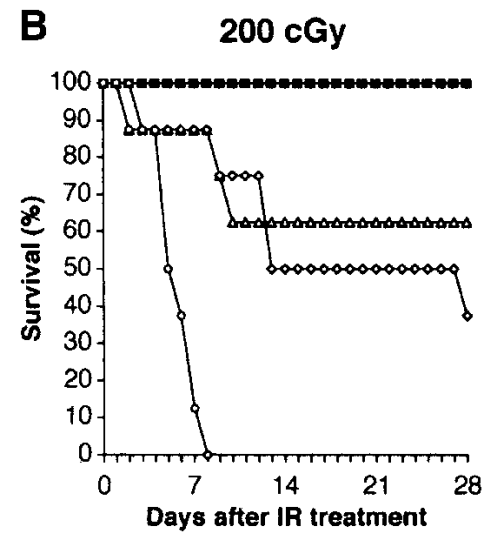




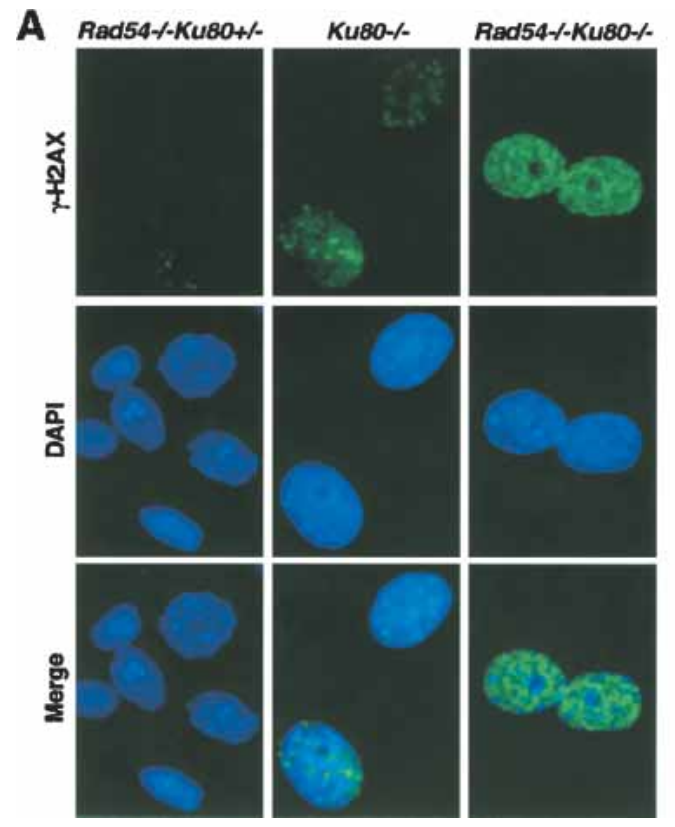

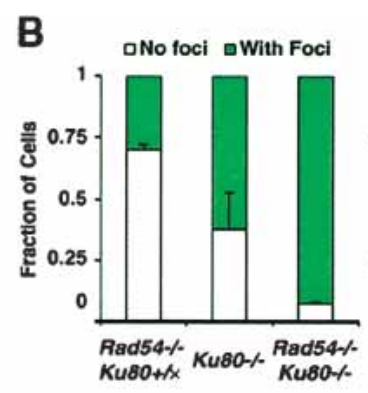

C

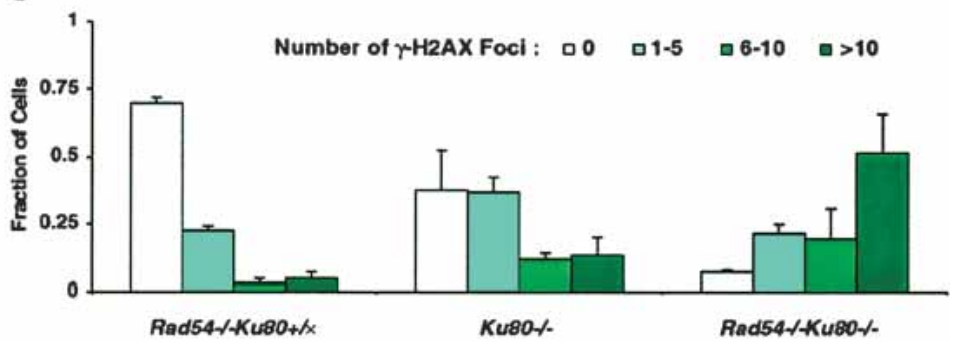

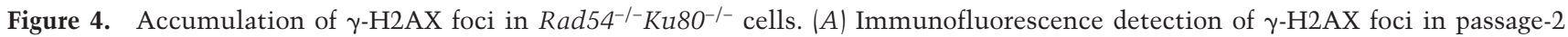
MEFs of indicated genotypes. (B) Fraction of cells with $\gamma$-H2AX foci (light-green bars) or no foci (white bars) is shown for each cell line

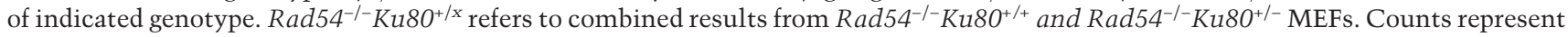
averages from two independent experiments. $(C)$ Fraction of cells exhibiting 0 (white bars), 1-5 (gray bars), 6-10 (light-green bars), or $>10$ (dark-green bars) $\gamma$-H2AX foci per nucleus. Counts represent averages from two independent experiments. $(D)$ Immunufluorescence detection of cleaved caspase-3 ( $\alpha$ Caspase-3) in UV-irradiated wild-type or $p 53^{-/-}$MEFs and in untreated wild-type,

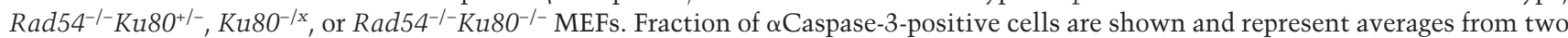
independent experiments.

premeiotic germ cells. Both Rad54 $4^{-/-}$and $\mathrm{Ku} 80^{-/-}$males are fertile (Nussenzweig et al. 1996; Essers et al. 1997), and $\mathrm{Ku} 80^{-1-}$ mice have been reported to have normal levels of apoptosis in the testis (Espejel et al. 2002). Therefore, we tested whether cellular defects could be detected in the testis of double-mutant animals, using histological analysis of 2-4-month-old animals.

As expected, testes from $\mathrm{Ku} 80^{-/-}$and $\mathrm{Rad} 54^{-/-} \mathrm{Ku} 8 \mathrm{O}^{+/-}$ animals showed normal testicular morphology and cellularity on gross observation, and the epididymides showed abundant sperm, similar to $\operatorname{Rad} 54^{+/-} \mathrm{Ku} 80^{+/-}$ control mice (Fig. 5A, panels i-v; data not shown). A few seminiferous tubules had apoptotic cells, as detected by TUNEL staining, which were generally located near the base of the tubule (arrowhead, Fig. 5A, panel iii). Usually there were just one or a few apoptotic cells per tubule, if any at all (Fig. 5B).

In contrast, results from $\mathrm{Rad} 54^{-/-} \mathrm{Ku} 80^{-/-}$mice were variable. Although the testes from one animal appeared normal (Fig. 5B, Rad54 $4^{-1-} \mathrm{Ku} 80^{-/-}$\#1), testes from two other double-mutant animals were quite aberrant. In one animal, there was a pronounced lack of cellularity in some tubules (Fig. 5A, panel vi, arrowhead). Other tubules in this animal were hypocellular, and these had a number of apoptotic cells both at the base of the tubule and more luminal (Fig. 5A, panels vi,vii; Rad54 $\left.4^{-/-} \mathrm{Ku} 80^{-I_{-}} \# 2\right)$, so that the overall number of tubules with apoptotic cells was increased (Fig. 5B). Not surprisingly, the sperm concentration in the epididymis was substantially reduced (Fig. 5A, panel viii). In another animal, there was only a single testis. The testis in this animal was more cellularized, but large numbers of apoptotic cells were apparent in most tubules (Fig. 5A,

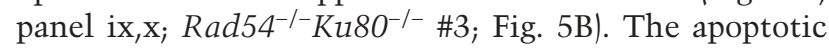
cells were also located at the base of the tubule and more luminal, and closer examination suggested that apoptotic cells included spermatogonia, spermatocytes, and spermatids. Again, the sperm concentration in the epididymis was substantially reduced (Fig. 5A, panel xi).

A summary of the apoptotic cell counts for three animals for each genotype shows that $\sim 10 \%$ of seminiferous tubules from the $\mathrm{Rad} 54^{-/-} \mathrm{Ku} 8 \mathrm{O}^{+/-}, \mathrm{Ku} 80^{-/-}$, and Rad54 ${ }^{+/-} \mathrm{Ku} 80^{-/-}$animals have two or more apoptotic cells, similar to $\mathrm{Rad} 54^{+/-} \mathrm{Ku} 80^{+/-}$mice (Fig. $5 \mathrm{C}$ ). For the Rad54 $4^{-/-} \mathrm{Ku} 80^{-/-}$mice, the range of apoptotic cells per tubule is more variable, but can reach $90 \%$ (Fig. 5C). The mean number of tubules with two or more apoptotic cells in the double mutant is greater than fourfold higher than the other genotypes, although the standard deviation is quite large, given the variability of phenotypes seen between the individual mice.

\section{Discussion}

In this study, we investigated the collaboration of HR and NHEJ components on survival of the mouse and on the DNA damage response. For this, we combined a mild HR mutation, Rad54, with the moderately affected 


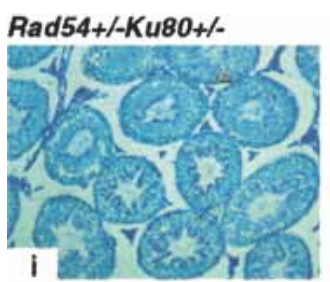

Ku80\%
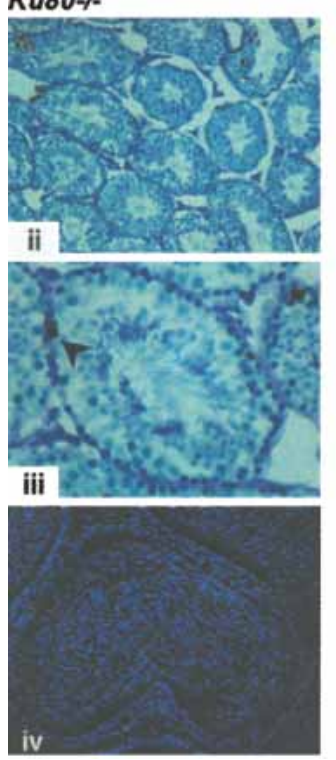

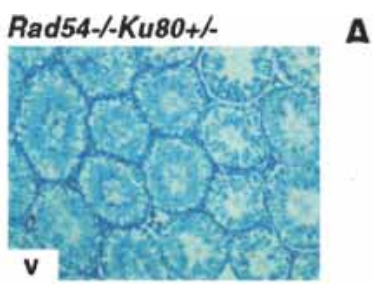

Rad54- - Ku80\% \#2

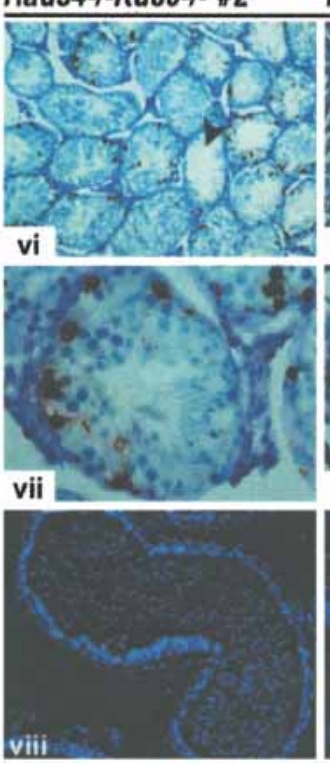

$\Delta$

Rad54- - -Ku80-\% \#3
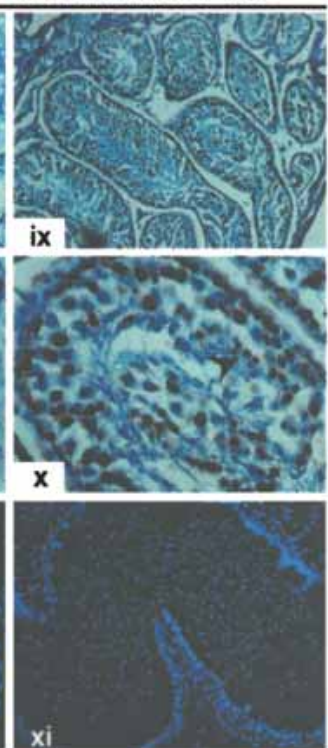

B
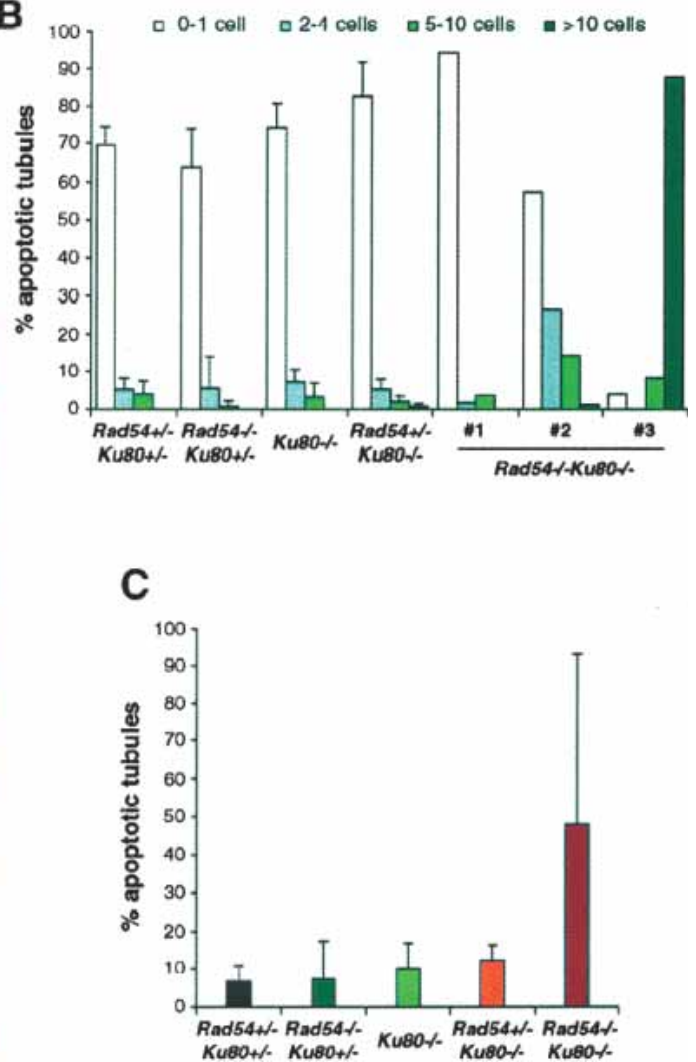

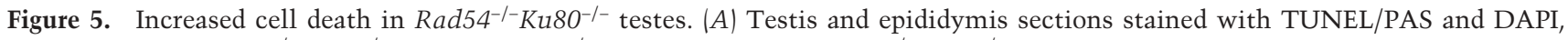

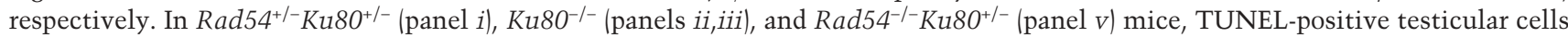
are rare, but when present, are usually located at the base of the seminiferous tubule (e.g., arrowhead in panel iii). Similar results were

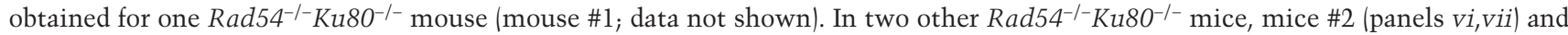
\#3 (panels $i x, x)$, TUNEL-positive cells are abundant. In mouse \#2, tubules with reduced cellularity and germ-cell depletion (arrowhead in panel vi) are evident. In mouse \#3, cellularity of tubules is not as visibly reduced, but TUNEL-positive cells are even more abundant, including round spermatids (arrowhead in panel $\mathrm{x}$ ). Mature sperm in the epididymis is abundant in all controls, including $\mathrm{Ku} 8 \mathrm{O}^{-/-}$mice

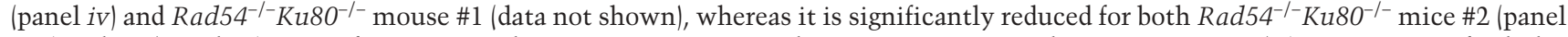
viii) and \#3 (panel xi). Magnification: panels i,ii,v,vi,ix, 100x; panels iii,vii,x, 400x; panels iv, viii,xi, 200x. (B) Percentages of tubules exhibiting 0 or 1 (white bars), 2-4 (gray bars), 5-10 (light-green bars), or >10 (dark-green bars) TUNEL-positive cells. Counts represent averages from three mice, except for $\mathrm{Rad} 54^{-/-} \mathrm{Ku} 80^{-/-}$mice, which are individually depicted. (C) Percentages of tubules exhibiting two or more TUNEL-positive cells. Counts represent averages from three mice.

NHEJ mutant Ku80. We find that $\mathrm{Rad} 54^{-/-} \mathrm{Ku} 80^{-/-}$mice are significantly compromised for their survival, such that by 31 wk of age, $\sim 10$-fold fewer double-mutant mice are alive than are Ku80 single-mutant mice. Loss of viability occurs at several stages, that is, during embryogenesis, immediately after birth, and after weaning. This contrasts with combined Rad54 and DNA-PKcs mutation, as Rad54 $4^{-/}$scid mice are not significantly compromised for viability (Essers et al. 2000; J. Essers and R.

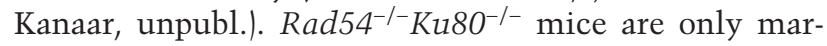
ginally smaller than $\mathrm{Ku} 80$ mutant mice and die mostly from unspecified causes. Lymphoma frequency is reduced for $\mathrm{Rad} 54^{-/-} \mathrm{Ku} 80^{-/-}$mice compared with $\mathrm{Ku} 80^{-/-}$ mice, presumably as a result of the earlier death of the double-mutant animals.

Our results imply that DNA damage repair is synergistically affected when both HR and NHEJ are impaired. Consistent with this, $\mathrm{Rad} 54^{-/-} \mathrm{Ku} 80^{-/-}$mice are exquis- itely sensitive to low doses of IR. Moreover, the DNA damage response is activated in double mutants in the absence of exogenous DNA damage: Spontaneous $\gamma$-H2AX foci are significantly elevated in embryonic fibroblasts and apoptosis is increased in testes in two of the three examined double-mutant animals. In the testis, neither $\mathrm{Rad} 54^{-{ }^{-}}$mice nor $\mathrm{Ku} 80^{-/-}$mice had elevated apoptosis compared with wild-type mice, whereas in the Rad54 ${ }^{-/-} \mathrm{Ku} 80^{-/-}$mouse with the most extreme phenotype, significant numbers of apoptotic cells were found in nearly every seminiferous tubule. That testicular apoptosis is not increased in all double-mutant animals, suggests incomplete penetrance or that a genetic modifier may be present (see Karanjawala et al. 2003). However, apoptosis was not markedly increased in the developing brain of $\mathrm{Rad} 54^{-/-} \mathrm{Ku} 8 \mathrm{O}^{-/-}$embryos. The high level of apoptosis in $\mathrm{Ku} 8 \mathrm{O}^{-/-}$animals may mask a contribution of Rad54, or alternatively, Rad54 may not have a 
significant role in the developing brain, unlike other HR factors (Deans et al. 2000). Our results, therefore, demonstrate that different tissues respond differentially to loss of the Rad54 and Ku80 DNA repair factors.

Many of the phenotypes we observed for Rad54 ${ }^{-/-} \mathrm{Ku}_{80} 0^{-/-}$mice are p53 dependent (C. Couëdel and M. Jasin, unpubl.). p53 heterozygosity substantially restores the viability of $\mathrm{Rad} 54^{-I^{-}} \mathrm{Ku} 8 \mathrm{O}^{-/-}$mice, decreases the neuronal apoptosis observed in embryonic brains, and marginally increases the weight of double-mutant animals. Complete loss of p53 may also abrogate the accumulation of $\gamma$-H2AX foci in the $\mathrm{Rad} 54^{-/-} \mathrm{Ku} 80^{-/-}$ MEFs, as is seen for Rad54 $4^{-/} \mathrm{Lig} 4^{-/-}$MEFs (Mills et al. 2004). Loss of p53, however, renders $\mathrm{Rad} 54^{-/-} \mathrm{Ku} 80^{-/-}$ mice susceptible to the same type of aggressive B-cell lymphomas containing chromosomal translocations and gene amplifications that are seen in $\mathrm{Ku} 80^{-/-} \mathrm{p} 53^{-/-}$mice (Difilippantonio et al. 2000, 2002). Taken together, p53 deficiency may therefore allow the use of alternate repair pathways as cells traverse the cell cycle unchecked.

Because HR and NHEJ are two genetically distinct repair pathways, they have been thought to act independently in a mutually exclusive fashion. Rad54 is part of the Rad52 epistasis group of genes that were originally identified as being involved in HR repair of IR damage in yeast (Symington 2002). Similar to yeast, Rad54 mutant mouse embryonic stem (ES) cells are IR sensitive and are deficient for HR, as measured by repair of a DSB, gene targeting, and damage-induced sister-chromatid exchange (Essers et al. 1997; Dronkert et al. 2000). The decrease in HR repair of a DSB is rather small compared with other HR mutants, which likely accounts for the lack of an embryonic phenotype for Rad54 $4^{-/-}$mice. In contrast to ES cells, Rad54 mutant mice are not sensitive to IR, even at such high doses as 7.5 Gy (Essers et al. 2000). As shown here, however, Rad54 mutation augments the IR sensitivity of Ku80 mutant mice, as it does with DNA-PKCs mutant mice (Essers et al. 2000), implying that Rad54 has a role in IR repair in adult animals when NHEJ is impaired. A synergistic increase in IR sensitivity was previously reported for $\mathrm{Rad} 54^{-/-} \mathrm{Ku} 7 \mathrm{O}^{-/-}$ Drosophila larvae and chicken cells, although in both of these systems, Rad54 mutation itself caused IR sensitivity (Takata et al. 1998; Kooistra et al. 1999).

Whereas Ku mutant cells have severely reduced NHEJ in the context of $V(D) J$ recombination (van Gent et al. 2001; Mills et al. 2003), the repair of an endonucleasegenerated DSB by HR has been shown to be increased in $\mathrm{Ku}$ mutant cells (Fukushima et al. 2001; Pierce et al. 2001a). This suggests that HR and NHEJ can be competing pathways for the repair of a DSB in some circumstances. Possibly, when Ku binds to DNA ends, it inhibits end-processing (Pellicioli et al. 2001) or another step of HR, such that in its absence, HR can compensate for NHEJ in DSB repair. This is further supported by the decreased IR sensitivity of Ku-deficient chicken cells at the cell cycle stage when HR is active; that is, late S/G2 (Takata et al. 1998).

The combined disruption of HR and NHEJ pathways would lead, therefore, to the accumulation of a substan- tial number of unrepaired DSBs. Consistent with this, we find that $\gamma-\mathrm{H} 2 \mathrm{AX}$ foci were present in nearly all Rad54 $4^{-/-} \mathrm{Ku} 80^{-/-}$cells, with a large portion of these cells having several foci. We cannot rule out, however, that some other lesion is being sensed instead of, or in addition to DSBs, as $\gamma$-H2AX foci may form in response to other signals (see Mahadevaiah et al. 2001). The increase in $\gamma$-H2AX foci in the double-mutant cells is much more than additive; although $\mathrm{Ku}^{-10^{-/}}$cells have a clear increase in foci compared with wild-type cells, Rad54 ${ }^{-/-}$ cells do not, such that the combined loss of Rad54 and $\mathrm{Ku}$ leads to a synergistic increase in this DNA damage response. This parallels results obtained with Rad54 $4^{-/} \mathrm{Lig}^{-/-}$cells, in which $\gamma$-H2AX foci accumulate to a high level, further strengthening a cooperative role for HR and NHEJ in DNA repair (Mills et al. 2004). As would be expected for cells with severely compromised DNA repair, HR and NHEJ double mutants accumulate a high level of chromosome abnormalities. In particular, Rad54 $4^{-/}$Lig $^{-/-}$cells accumulate a high number of chromatid breaks (Mills et al. 2004), as do Rad54 $4^{-1-} \mathrm{Ku} 70^{-/-}$ chicken cells (Takata et al. 1998).

It is interesting to speculate on the lesion(s) that arise at high frequency as a result of combined Rad54 and Ku80 deficiency, especially those that may lead to DNA breaks. HR is considered to be of primary importance during S and G2 (Fig. 6, blue arrows; Takata et al. 1998; Rothkamm et al. 2003). Consistent with this, the primary template for HR repair, that is, sister chromatids (Johnson and Jasin 2000), is available during these cell cycle phases. Although NHEJ is considered to play a key role in DSB repair during G1 (Takata et al. 1998), it is operational throughout the cell cycle (Fig. 6, green arrows; Rothkamm et al. 2003) and can even be coupled to HR for the repair of a single DSB (Fig. 6, red arrow; Richardson and Jasin 2000). HR is thought to be of critical importance for repair of lesions resulting from replication blocks (Saintigny et al. 2001; Rothkamm et al. 2003), such that replication can be restarted (Cromie et al. 2001). DSBs arising in the context of replication are expected to primarily be one-ended (Fig. 6, arrow 1), which would not be faithfully repaired by NHEJ. One

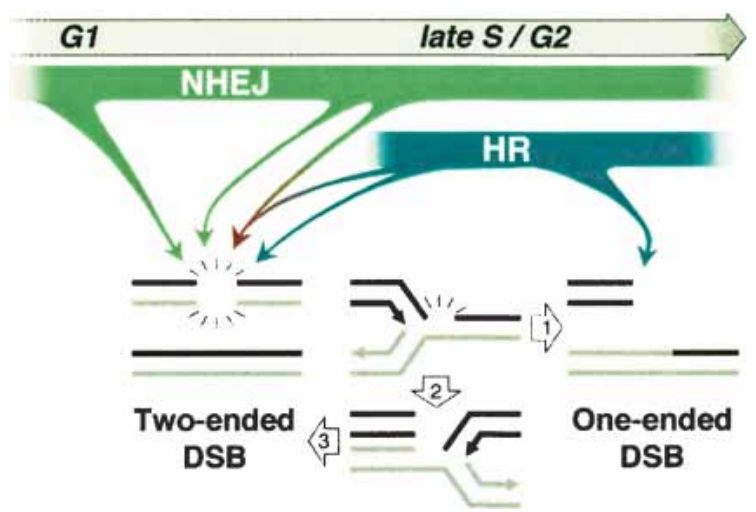

Figure 6. Relative contribution of NHEJ and HR in repair of DSBs. See text for details. 
possibility is that if $\mathrm{HR}$ is impaired, such that replication cannot be restarted from a one-ended DSB, replication from the adjacent fork proceeds to the stalled fork (Fig. 6, arrow 2), and then itself is stalled, forming a second end (Fig. 6, arrow 3), which can be joined to the first end by NHEJ. Alternatively, more conventional two-ended DSBs that can be acted upon by HR or NHEJ may arise from processes other than DNA replication, for example, oxidative metabolism or processing of aberrant DNA structures. Notably, both HR and NHEJ can participate in resolving abnormal DNA structures that arise at palindromic sequences in mice (Zhou et al. 2001; Cunningham et al. 2003). Identifying the origin of DSBs and other lesions that arise in cells will clearly be important for determining how genomic integrity can be compromised. Understanding the cooperative roles of $\mathrm{HR}$ and NHEJ components in the repair of such lesions adds another layer of complexity to understanding how genomic integrity is maintained.

\section{Materials and methods}

\section{Generation and screening of mice}

Ku80 and Rad54 mutant mice have been previously generated (Nussenzweig et al. 1996; Essers et al. 1997). (See Supplementary Table 1 for crosses and genotyping details.) Genotyping of the mice obtained from maternal nursing was done at weaning (i.e., $21 \mathrm{~d}$ of age). For those animals that were fostered, $\mathrm{Ku} 8 \mathrm{O}^{-/-}$ mice of any Rad54 genotype were identified at birth by their small size, placed with foster mothers, and monitored daily. At weaning, food was placed on the bottom of the cage for easy access by the mutant mice. To ascertain the genotypes of newborn animals, pups were counted at birth and any animals that were found dead on the day of birth up until $10 \mathrm{~d}$ of age were collected for genotyping. All animals remaining alive at $10 \mathrm{~d}$ were genotyped at that time.

\section{Statistical analysis}

For each genotype, percent recovery was determined by dividing the observed number of mice by the expected number of mice, calculated according to the Mendelian frequencies. (See Supplementary Table 1 for the breakdown of mice derived from each cross.) Significance of comparisons was assessed by simulation. As part of this process, null distributions were simulated in a hierarchical manner. First, the numbers of mice corresponding to a particular type of cross were assigned on the basis of the trinomial distribution with parameters following the observed data in Supplementary Table 1. Second, the numbers of mice within crosses were apportioned assuming Hardy-Weinberg equilibrium. The observed counts were compared with the resulting distributions of expected counts to test for compromised viability. In addition, from the same simulations, the counts of observed to expected were compared between the $\mathrm{Ku}_{80} \mathrm{O}^{-/}$or Rad54+/- $\mathrm{Ku} 80^{-/-}$and $\mathrm{Rad} 54^{-/-} \mathrm{Ku} 80^{-/-}$mice. The test statistic used was the ratio of observed over expected between groups (Table 1). The simulations were repeated 10,000 times. Lymphoma rates among viable mice were compared using Fisher's exact test. All p-values are two-sided.

\section{Histopathology}

Complete postmortem evaluations were performed on fostered mice that were at least $10 \mathrm{~d}$ old. Tissues were fixed in $10 \%$ neutral-buffered formalin overnight, processed by routine methods, and embedded in paraffin wax. Sections (5 $\mu \mathrm{m})$ were stained with hematoxylin and eosin, and major organs (heart, lungs, kidneys, liver, spleen, thymus, and brain) were evaluated with an Olympus BX45 light microscope (New York/New Jersey Scientific, Inc.).

\section{Mouse embryonic fibroblasts}

MEFs were obtained from E13.5 embryos after removal of the organ block tissue, the head (used for histological analysis), and the tail along with the back legs (used for genotyping). Cells were grown in DME-HG medium supplemented with $10 \%$ fetal calf serum (FCS), 1\% L-Glutamine, and antibiotics in a $5 \%$ $\mathrm{CO}_{2}$-humidified, $37^{\circ} \mathrm{C}$ incubator. For detection of $\gamma$-H2AX foci, passage-2 MEFs were grown on sterilized, gelatinized coverslips. Cells were washed with PBS and fixed for $10 \mathrm{~min}$ in 3\% formaldehyde $/ 2 \%$ glucose, followed by a 10 -min permeabilization with $0.1 \%$ Triton X-100 in PBS prior to overnight incubation with polyclonal rabbit $\alpha-\gamma$-H2AX antibody (Bassing et al. 2002) in $2 \% \mathrm{FCS} / \mathrm{PBS}$ at $4^{\circ} \mathrm{C}$. Cells were then washed with three changes of PBS and incubated for $1 \mathrm{~h}$ at room temperature with FITC-conjugated goat anti-rabbit secondary antibody (Vector Laboratories). Nuclear DNA was stained with DAPI and coverslips were mounted with Vectashield mounting medium. Images were captured on a Nikon microscope using black and white CCD camera, and analyzed using Applied Spectral Imaging software.

\section{Histological analysis}

Testes and epididymides from 24 month-old mice were fixed in $4 \%$ paraformaldehyde or Bouin's solution, respectively, paraffin embedded, and serially sectioned $(8 \mu \mathrm{m})$. Epididymis sections were stained with DAPI to detect nuclei, and coverslips were mounted with Vectashield mounting medium (Molecular Probe). A terminal deoxynucleotidyl transferase (TdT)-mediated dUTP biotin nick end-labeling (TUNEL) assay was performed on testes sections as follows: after dewaxing, rehydration, and proteinase $\mathrm{K}$ treatment for $15 \mathrm{~min}$, sections were fixed in $4 \%$ paraformaldehyde for $10 \mathrm{~min}$, and endogenous peroxidase was quenched in $0.1 \% \mathrm{H}_{2} \mathrm{O}_{2}$ for $15 \mathrm{~min}$. TdT (Roche)-mediated dUTP-biotin (Roche) labeling was performed at $37^{\circ} \mathrm{C}$ for $2 \mathrm{~h}$ in a humid chamber and amplified with $\mathrm{A} \& \mathrm{~B}$ reagents (Vector Laboratories) in a room temperature, humid chamber for 30-60 min. In some cases, an additional amplification step was performed using the TSA Biotin System (Perkin Elmer) for 15 min according to the supplier's instructions, followed by an additional 30-min amplification step with A\&B reagents. Triton $\mathrm{X}$-100-treated sections were then stained with diaminobenzidine (DAB) and counterstained with periodic acid-Schiff (PAS) prior to mounting in permount.

\section{Irradiation}

Two- to four-month-old animals were simultaneously exposed to ionizing radiation from a ${ }^{137} \mathrm{Cs}$ source and observed daily for $28 \mathrm{~d}$. Two groups of six or eight $\mathrm{Ku}_{80^{-/-}}$, Rad54+/- $\mathrm{Ku} 80^{-/-}$, and Rad54 ${ }^{-/-} \mathrm{Ku} 80^{-/-}$mice (females and males) were exposed to either 100 or $200 \mathrm{cGy}$, respectively. The effects of $\gamma$-irradiation on

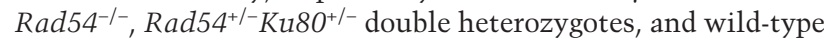
littermates were identical, and those three genotypes were used as controls. Two mice (one female and one male) of each genotype were used for both experiments. 


\section{Acknowledgments}

We thank Dr. Katia Manova and the staff of the Molecular Cytology Core Facility at MSKCC for help and advice in histology. We also thank Dr. Krista La Perle from the Genetically Engineered Mouse Phenotyping Core at MSKCC for performing the necropsies and helpful discussion. This work was supported in part by the Association pour la Recherche contre le Cancer (C.C.), the Lalor Foundation (M.B.), an American-Italian Cancer Foundation Fellowship (M.B.), and NIH grants CA56909 (G.C.L), CA78497 (G.C.L), GM54668 (M.J.), and HD40916 (M.J.).

The publication costs of this article were defrayed in part by payment of page charges. This article must therefore be hereby marked "advertisement" in accordance with 18 USC section 1734 solely to indicate this fact.

\section{References}

Allen, C., Kurimasa, A., Brenneman, M.A., Chen, D.J., and Nickoloff, J.A. 2002. DNA-dependent protein kinase suppresses double-strand break-induced and spontaneous homologous recombination. Proc. Nat1. Acad. Sci. 99:37583763.

Bassing, C.H., Chua, K.F., Sekiguchi, J., Suh, H., Whitlow, S.R., Fleming, J.C., Monroe, B.C., Ciccone, D.N., Yan, C., Vlasakova, K., et al. 2002. Increased ionizing radiation sensitivity and genomic instability in the absence of histone H2AX. Proc. Nat1. Acad. Sci. 99: 8173-8178.

Cromie, G.A., Connelly, J.C., and Leach, D.R. 2001. Recombination at double-strand breaks and DNA ends: Conserved mechanisms from phage to humans. Mol. Cell 8: 1163-1174.

Cunningham, L.A., Cote, A.G., Cam-Ozdemir, C., and Lewis, S.M. 2003. Rapid, stabilizing palindrome rearrangements in somatic cells by the center-break mechanism. Mol. Cell. Biol. 23: 8740-8750.

Deans, B., Griffin, C.S., Maconochie, M., and Thacker, J. 2000. Xrcc2 is required for genetic stability, embryonic neurogenesis and viability in mice. EMBO J. 19: 6675-6685.

Delacote, F., Han, M., Stamato, T.D., Jasin, M., and Lopez, B.S. 2002. An xrcc4 defect or Wortmannin stimulates homologous recombination specifically induced by double-strand breaks in mammalian cells. Nucleic Acids Res. 30: 34543463.

Difilippantonio, M.J., Zhu, J., Chen, H.T., Meffre, E., Nussenzweig, M.C., Max, E.E., Ried, T., and Nussenzweig, A. 2000. DNA repair protein Ku80 suppresses chromosomal aberrations and malignant transformation. Nature 404: 510-514.

Difilippantonio, M.J., Petersen, S., Chen, H.T., Johnson, R., Jasin, M., Kanaar, R., Ried, T., and Nussenzweig, A. 2002. Evidence for replicative repair of DNA double-strand breaks leading to oncogenic translocation and gene amplification. $J$. Exp. Med. 196: 469-480.

Dronkert, M.L., Beverloo, H.B., Johnson, R.D., Hoeijmakers, J.H., Jasin, M., and Kanaar, R. 2000. Mouse RAD54 affects DNA double-strand break repair and sister chromatid exchange. Mol. Cell. Biol. 20: 3147-3156.

Espejel, S., Franco, S., Rodriguez-Perales, S., Bouffler, S.D., Cigudosa, J.C., and Blasco, M.A. 2002. Mammalian Ku86 mediates chromosomal fusions and apoptosis caused by critically short telomeres. EMBO J. 21: 2207-2219.

Essers, J., Hendriks, R.W., Swagemakers, S.M., Troelstra, C., de Wit, J., Bootsma, D., Hoeijmakers, J.H., and Kanaar, R. 1997. Disruption of mouse RAD54 reduces ionizing radiation resistance and homologous recombination. Cell 89: 195-204.
Essers, J., van Steeg, H., de Wit, J., Swagemakers, S.M., Vermeij, M., Hoeijmakers, J.H., and Kanaar, R. 2000. Homologous and non-homologous recombination differentially affect DNA damage repair in mice. EMBO J. 19: 1703-1710.

Fukushima, T., Takata, M., Morrison, C., Araki, R., Fujimori, A., Abe, M., Tatsumi, K., Jasin, M., Dhar, P.K., Sonoda, E., et al. 2001. Genetic analysis of the DNA-dependent protein kinase reveals an inhibitory role of $\mathrm{Ku}$ in late S-G2 phase DNA double-strand break repair. J. Biol. Chem. 276: 44413 44418.

Gu, Y., Seidl, K.J., Rathbun, G.A., Zhu, C., Manis, J.P., van der Stoep, N., Davidson, L., Cheng, H.L., Sekiguchi, J.M., Frank, K., et al. 1997. Growth retardation and leaky SCID phenotype of Ku70-deficient mice. Immunity 7: 653-665.

Gu, Y., Sekiguchi, J., Gao, Y., Dikkes, P., Frank, K., Ferguson, D., Hasty, P., Chun, J., and Alt, F.W. 2000. Defective embryonic neurogenesis in Ku-deficient but not DNA-dependent protein kinase catalytic subunit-deficient mice. Proc. Natl. Acad. Sci. 97: 2668-2673.

Jasin, M. 2002. Homologous repair of DNA damage and tumorigenesis: The BRCA connection. Oncogene 21: 8981-8993.

Johnson, R.D. and Jasin, M. 2000. Sister chromatid gene conversion is a prominent double-strand break repair pathway in mammalian cells. EMBO J. 19: 3398-3407.

Karanjawala, Z.E., Hsieh, C.L., and Lieber, M.R. 2003. Overexpression of $\mathrm{Cu} / \mathrm{Zn}$ superoxide dismutase is lethal for mice lacking double-strand break repair. DNA Repair 2: 285-294.

Keeney, S. 2001. Mechanism and control of meiotic recombination initiation. Curr. Top. Dev. Biol. 52: 1-53.

Kooistra, R., Pastink, A., Zonneveld, J.B., Lohman, P.H., and Eeken, J.C. 1999. The Drosophila melanogaster DmRAD54 gene plays a crucial role in double-strand break repair after $\mathrm{P}$-element excision and acts synergistically with $\mathrm{Ku} 70$ in the repair of X-ray damage. Mol. Cell. Biol. 19: 6269-6275.

Li, G.C., Ouyang, H., Li, X., Nagasawa, H., Little, J.B., Chen, D.J., Ling, C.C., Fuks, Z., and Cordon-Cardo, C. 1998. Ku70: A candidate tumor suppressor gene for murine $\mathrm{T}$ cell lymphoma. Mol. Cell 2: 1-8.

Liang, F., Han, M., Romanienko, P.J., and Jasin, M. 1998. Homology-directed repair is a major double-strand break repair pathway in mammalian cells. Proc. Natl. Acad. Sci. 95: 5172-5177.

Mahadevaiah, S.K., Turner, J.M., Baudat, F., Rogakou, E.P., de Boer, P., Blanco-Rodriguez, J., Jasin, M., Keeney, S., Bonner, W.M., and Burgoyne, P.S. 2001. Recombinational DNA double-strand breaks in mice precede synapsis. Nat. Genet. 27: 271-276.

Mills, K.D., Ferguson, D.O., and Alt, F.W. 2003. The role of DNA breaks in genomic instability and tumorigenesis. Immunol. Rev. 194: 77-95.

Mills, K.D., Ferguson, D.O., Essers, J., Eckersdorff, M., Kanaar, R., and Alt, F.W. 2004. Rad54 and DNA Ligase IV cooperate to maintain mammalian chromatid stability. Genes \& Dev. (this issue).

Nussenzweig, A., Chen, C., da Costa Soares, V., Sanchez, M., Sokol, K., Nussenzweig, M.C., and Li, G.C. 1996. Requirement for Ku80 in growth and immunoglobulin V(D)J recombination. Nature 382: 551-555.

Nussenzweig, A., Sokol, K., Burgman, P., Li, L., and Li, G.C. 1997. Hypersensitivity of Ku80-deficient cell lines and mice to DNA damage: The effects of ionizing radiation on growth, survival, and development. Proc. Nat1. Acad. Sci. 94: 1358813593.

Paques, F. and Haber, J.E. 1999. Multiple pathways of recombination induced by double-strand breaks in Saccharomyces cerevisiae. Microbiol. Mol. Biol. Rev. 63: 349-404. 


\section{Couëdel et al.}

Pellicioli, A., Lee, S.E., Lucca, C., Foiani, M., and Haber, J.E. 2001. Regulation of Saccharomyces Rad53 checkpoint kinase during adaptation from DNA damage-induced G2/M arrest. Mol. Cell 7: 293-300.

Pierce, A.J., Hu, P., Han, M., Ellis, N., and Jasin, M. 2001a. Ku DNA end-binding protein modulates homologous repair of double-strand breaks in mammalian cells. Genes \& Dev. 15: 3237-3242.

Pierce, A.J., Stark, J.M., Araujo, F.D., Moynahan, M.E., Berwick, M., and Jasin, M. 2001b. Double-strand breaks and tumorigenesis. Trends Cell. Biol. 11: S52-S59.

Richardson, C. and Jasin, M. 2000. Coupled homologous and nonhomologous repair of a double-strand break preserves genomic integrity in mammalian cells. Mol. Cell. Biol. 20: 9068-9075.

Rogakou, E.P., Pilch, D.R., Orr, A.H., Ivanova, V.S., and Bonner, W.M. 1998. DNA double-stranded breaks induce histone H2AX phosphorylation on serine 139. I. Biol. Chem. 273: 5858-5868.

Rogakou, E.P., Boon, C., Redon, C., and Bonner, W.M. 1999. Megabase chromatin domains involved in DNA doublestrand breaks in vivo. J. Cell Biol. 146: 905-916.

Rothkamm, K., Kruger, I., Thompson, L.H., and Lobrich, M. 2003. Pathways of DNA double-strand break repair during the mammalian cell cycle. Mol. Cell. Biol. 23: 5706-5715.

Rouet, P., Smih, F., and Jasin, M. 1994. Introduction of doublestrand breaks into the genome of mouse cells by expression of a rare-cutting endonuclease. Mol. Cell. Biol. 14: 8096-8106.

Saintigny, Y., Delacote, F., Vares, G., Petitot, F., Lambert, S., Averbeck, D., and Lopez, B.S. 2001. Characterization of homologous recombination induced by replication inhibition in mammalian cells. EMBO J. 20: 3861-3870.

Symington, L.S. 2002. Role of RAD52 epistasis group genes in homologous recombination and double-strand break repair. Microbiol. Mol. Biol. Rev. 66: 630-670.

Takata, M., Sasaki, M.S., Sonoda, E., Morrison, C., Hashimoto, M., Utsumi, H., Yamaguchi-Iwai, Y., Shinohara, A., and Takeda, S. 1998. Homologous recombination and non-homologous end-joining pathways of DNA double-strand break repair have overlapping roles in the maintenance of chromosomal integrity in vertebrate cells. EMBO J. 17: 5497-5508. van Gent, D.C., Hoeijmakers, J.H., and Kanaar, R. 2001. Chromosomal stability and the DNA double-stranded break connection. Nat. Rev. Genet. 2: 196-206.

West, S.C. 2003. Molecular views of recombination proteins and their control. Nat. Rev. Mol. Cell. Biol. 4: 435-445.

Zhou, Z.H., Akgun, E., and Jasin, M. 2001. Repeat expansion by homologous recombination in the mouse germ line at palindromic sequences. Proc. Natl. Acad. Sci. 98: 8326-8333. 


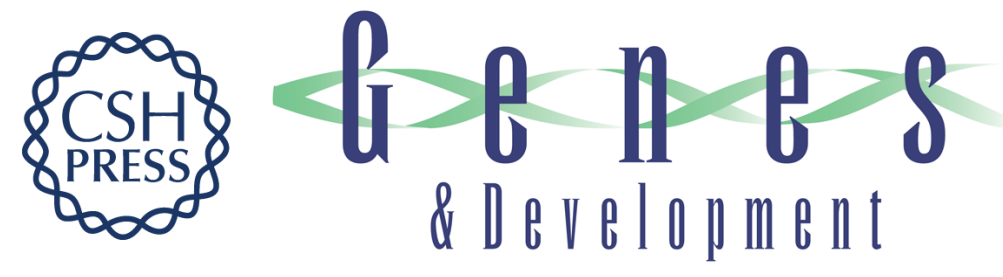

\section{Collaboration of homologous recombination and nonhomologous end-joining factors for the survival and integrity of mice and cells}

Chrystelle Couëdel, Kevin D. Mills, Marco Barchi, et al.

Genes Dev. 2004, 18:

Access the most recent version at doi:10.1101/gad.1209204

Supplemental http://genesdev.cshlp.org/content/suppl/2004/05/12/18.11.1293.DC1
Material

References This article cites 41 articles, 25 of which can be accessed free at:

http://genesdev.cshlp.org/content/18/11/1293.full.html\#ref-list-1

License

Email Alerting Receive free email alerts when new articles cite this article - sign up in the box at the top

Service right corner of the article or click here.

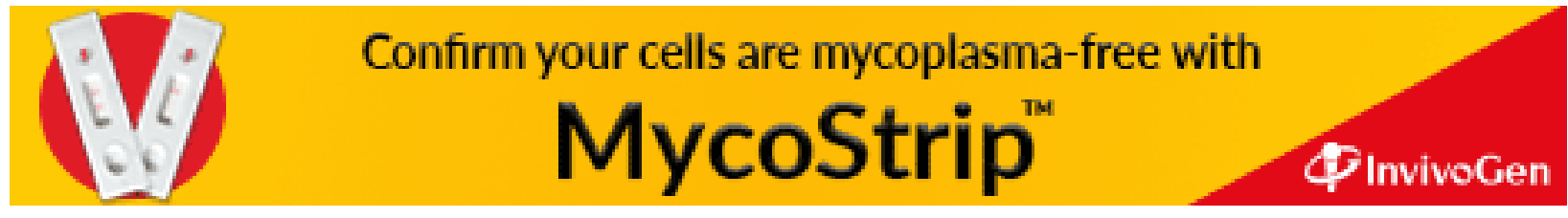

